\title{
Stable albicidin resistance in Escherichia coli involves an altered outer-membrane nucleoside uptake system
}

\author{
Robert G. Birch, ${ }^{1 *}$ John M. Pemberton $^{2}$ and W. V. Shiromi Basnayake ${ }^{1}$ \\ ${ }^{1}$ Department of Botany and ${ }^{2}$ Department of Microbiology, University of Queensland, St Lucia 4067, Australia
}

(Received 30 May 1989; accepted 29 September 1989)

\begin{abstract}
Albicidin blocked DNA synthesis in intact cells of a PolA- EndA- Escherichia coli strain, and in permeabilized cells supplied with all necessary precursor nucleotides, indicating a direct effect on prokaryote DNA replication. Replication of phages T4 and T7 was also blocked by albicidin in albicidin-sensitive (Albs) but not in albicidinresistant $\left(\mathrm{Alb}^{\mathrm{r}}\right) \mathrm{E}$. coli host-cells. All stable spontaneous $\mathrm{Alb}^{\mathrm{r}}$ mutants of $E$. coli simultaneously became resistant to phage T6. The locus determining albicidin sensitivity mapped at $t s x$, the structural gene for an outer-membrane protein used as a receptor by phage $\mathrm{T} 6$ and involved in transport through the outer membrane of nucleosides present at submicromolar extracellular concentrations. Albicidin does not closely resemble a nucleoside in structure. However, $\mathbf{A l b}^{\mathrm{s}} \mathrm{E}$. coli strains rapidly accumulated both nucleosides and albicidin from the surrounding medium whereas the Albr mutants were defective in uptake of nucleosides and albicidin at low extracellular concentrations. An insertion mutation blocking Tsx protein production also blocked albicidin uptake and conveyed albicidin resistance. Albicidin supplied at approximately $0 \cdot 1 \mu \mathrm{M}$ blocked DNA replication within seconds in intact $A^{\prime} b^{s} E$. coli cells, but a 100-fold higher albicidin concentration was necessary for a rapid inhibition of DNA replication in permeabilized cells. We conclude that albicidin is effective at very low concentrations against $E$. coli because it is rapidly concentrated within cells by illicit transport through the tsx-encoded outer-membrane channel normally involved in nucleoside uptake. Albicidin resistance results from loss of the mechanism of albicidin transport through the outer membrane.
\end{abstract}

\section{Introduction}

Chlorosis-inducing isolates of Xanthomonas albilineans, the sugarcane leaf scald pathogen, produce a family of antibacterial compounds in culture. The major component, named albicidin, has been partially characterized as a novel, low-molecular-mass antibiotic which is rapidly bactericidal to a range of Gram-positive and Gram-negative bacteria at concentrations as low as $1 \mathrm{ng}$ $\mathrm{ml}^{-1}$ (Birch \& Patil, 1985 ). Inhibition of prokaryote DNA replication was identified as the primary mode of action of albicidin, based on studies of incorporation of labelled precursors (Birch \& Patil, 1985a). A combination of ultrastructural, genetic and biochemical evidence indicates that a member of the albicidin family of toxins produced by $X$. albilineans in invaded xylem causes chlorosis in sugarcane leaf scald disease by blocking plastid DNA replication, resulting in blocked chloroplast differentiation (Birch \& Patil, 1983, 1987a, b). Albicidins are, therefore, of interest as phytotoxins, potential clinical antibiotics, and as tools to study prokaryotic DNA replication. We are particularly interested in bacterial genes encoding different mechanisms of albicidin resistance as candidates for transfer to plants, with the long-term aim of producing recombinant albicidin-resistant sugarcane cultivars.

We report here that stable albicidin resistance in Escherichia coli occurs by loss of a nucleoside transport mechanism involved in rapid, illicit intracellular accumulation of albicidin.

\section{Methods}

Bacterial and phage strains. Xanthomonas albilineans strains LS116, LS136 and LS155 were isolated from diseased sugarcane from Queensland, Australia. Strains of E. coli used are described in Table 1. Bacteriophages T4, T6 and T7 were obtained from Dr L. Sly, UQM culture collection (Dept of Microbiology, Univ. of Queensland).

Albicidin production. Albicidins produced in culture by $X$. albilineans were purified as described previously (Birch \& Patil, 1985a), except that Merck Fractogel TSK HW-40(S) replaced Sephadex LH-20 for gel-filtration in methanol. This change was necessary because all recently tested batches of Sephadex LH-20 irreversibly adsorbed albicidin. The manufacturers of Sephadex (Pharmacia) indicated that the highly aromatic structure of albicidin may result in different degrees of adsorption to different batches of LH-20. 
Table 1. E. coli strains used

All strains are E. coli $\mathrm{K} 12$, except HB101 and RRI which are $E$. coli $\mathrm{K} 12 \times E$. coli $\mathrm{B}$ hybrids and UQM70 which is a local isolate used for albicidin assays.

\begin{tabular}{|c|c|c|c|c|}
\hline \multirow{2}{*}{$\begin{array}{l}\text { Strain } \\
\text { designation }\end{array}$} & \multirow[b]{2}{*}{ Genotype } & \multicolumn{2}{|c|}{ Reaction to: } & \multirow{2}{*}{$\begin{array}{l}\text { Source or } \\
\text { reference } \dagger\end{array}$} \\
\hline & & Albicidin* & T6 & \\
\hline BRE2050 & \multirow{2}{*}{$\begin{array}{l}\mathrm{F}^{-} \text {met } B \text { ilv rpsL cytR9 deoR8 } \Delta(\arg F-\text { lac }) U 169 \\
\mathrm{~F}^{-} \text {ara leuB tonA lacY proC tsx-67 purE galK trpE his argG } \\
\text { malA rpsL xyl mtl ilvA metA thi supE } \lambda^{-}\end{array}$} & $\mathbf{S}$ & $\mathbf{S}$ & Bremer et al. (1988) \\
\hline CSH57A & & $\mathbf{R}$ & $\mathbf{R}$ & B. Bachmann \\
\hline EMG2 & $\mathrm{F}^{+}$, wild-type & $\mathbf{S}$ & $\mathbf{S}$ & B. Bachmann \\
\hline GP4 & BRE2050 $\Phi(t s x-l a c Z) l(\mathrm{Hyb})$ & $\mathbf{R}$ & $\mathbf{R}$ & Bremer et al. (1988) \\
\hline HB101 & $\mathrm{F}_{\lambda^{-}}^{-} h s d S\left(\mathrm{r}^{-} \mathrm{m}^{-}\right)$recA ara proA lacY galK rpoL xyl mtl supE & $\mathbf{S}$ & $\mathbf{S}$ & Maniatis et al. (1982) \\
\hline HB101 Albr & \multirow[b]{2}{*}{$\begin{array}{l}\mathrm{F}^{-} \text {rec } A \text { ara leuB azi tonA lacZ proC tsx-67 purE trpE rpsL } \\
\text { xyl mtl metE thi supE } \lambda^{-}\end{array}$} & $\mathbf{R}$ & $\mathbf{R}$ & This study \\
\hline KL251 & & $\mathrm{S}$ & $\mathbf{R}$ & B. Bachmann \\
\hline KL251 Albr & & $\mathbf{R}$ & $\mathbf{R}$ & This study \\
\hline KMBL1789 & & $\mathrm{S}$ & $\mathbf{S}$ & B. Bachmann \\
\hline LE392 & & $\mathbf{S}$ & $\mathrm{S}$ & Maniatis et al. (1982) \\
\hline LE392 Albr & $\mathrm{F}^{-} h s d R\left(\mathrm{r}^{-} \mathrm{m}^{+}\right)$lac Y galK galT metB trpR supE supF $\lambda^{-}$ & $\mathbf{R}$ & $\mathbf{R}$ & This study \\
\hline P1694 & & $\mathbf{S}$ & $\mathbf{S}$ & \\
\hline P1744 & $\begin{array}{l}\mathrm{F}^{-} \text {thr ara leu proA lacY galK rpsL xyl mtl argE thi supE } \lambda^{-} \\
\text {tsx-206 }\end{array}$ & $\mathbf{S}$ & $\mathbf{R}$ & \\
\hline P1807 & \multirow{2}{*}{$\left.\begin{array}{l}t s x-211 \\
t s x-212\end{array}\right\}$ Mutants of strain P1694 } & $\mathbf{R}^{\mathbf{c}}$ & $\mathbf{R}$ & \\
\hline P1808 & & $\mathbf{R}^{\mathbf{c}}$ & $\mathbf{R}$ & $\begin{array}{l}\text { Mannings \& } \\
\text { Reeves (1978) }\end{array}$ \\
\hline P1809 & 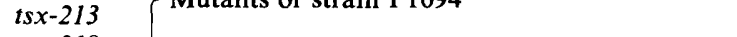 & $\mathbf{R}^{\mathbf{c}}$ & $\mathbf{R}$ & \\
\hline P1814 & $t s x-218$ & $\mathbf{R}^{\mathbf{c}}$ & $\mathbf{R}$ & \\
\hline P1816 & $t s x-220 \quad 3 \quad t$ & $\mathbf{R}^{\mathbf{c}}$ & $\mathbf{R}$ & \\
\hline Q358 & & $\mathbf{S}$ & $\mathbf{S}$ & Maniatis et al. (1982) \\
\hline Q358 Rif & \multirow{2}{*}{$h s d R\left(\mathrm{r}^{-} \mathrm{m}^{+}\right) \sup E \phi 80^{\mathrm{R}}$} & $\mathbf{S}$ & $\mathrm{S}$ & This study \\
\hline Q358 $\mathrm{Alb}^{\mathrm{r}}$ & & $\mathbf{R}$ & $\mathbf{R}$ & This study \\
\hline RRI & \multirow[t]{2}{*}{$\operatorname{rec} \mathrm{A}^{+}$derivative of $\mathrm{HB} 101$} & $\mathbf{S}$ & $\mathbf{S}$ & Maniatis et al. (1982) \\
\hline RRI Albr & & $\mathbf{R}$ & $\mathbf{R}$ & This study \\
\hline UQM 70 & Prototrophic, $\mathrm{Val}^{\mathrm{K}}$ wild-type & $\mathbf{S}$ & $\mathbf{S}$ & \\
\hline W3747 & $\begin{array}{l}\mathrm{F}^{\prime}(\text { episome } \mathrm{F} 13 ; \arg F \text { lac tsx }-69 \text { purE) relA spoT metB } \Delta \\
\text { corresponding to } \mathrm{F} 13\end{array}$ & $\mathbf{R}$ & $\mathbf{R}$ & L. Sly, Dept of \\
\hline$\chi 148$ & $\begin{array}{l}\mathrm{F}^{-} \text {ara leuB azi tonA lac Y tsx-67 purE galK trpE rpsL xyl } \\
\text { mtl thi supE } \lambda^{-}\end{array}$ & $\mathbf{R}$ & $\mathbf{R}$ & $\begin{array}{l}\text { Microbiology, Univ. of } \\
\text { Queensland }\end{array}$ \\
\hline$\chi 342$ & Hfr proC relA spoT metB $\lambda^{-}$ & $\mathbf{S}$ & $\mathrm{S}$ & \\
\hline$\chi 478$ & lys $A$ rec $A^{+}$parent of KL251 & $\mathbf{R}$ & $\mathbf{R}$ & J \\
\hline $294 \mathrm{RecA}^{-}$ & \multirow[t]{2}{*}{$\overline{\mathrm{F}}^{-}(?) h s d R\left(\mathrm{r}^{-} \mathrm{m}^{+}\right)$recA endA thi supE $\lambda^{-}$} & S & S & Uhlin et al. (1983) \\
\hline $294 \operatorname{Rec}^{-}$Alb $^{r}$ & & $\mathbf{R}$ & $\mathbf{R}$ & This study \\
\hline
\end{tabular}

${ }^{*} \mathbf{R}^{\mathrm{c}}$ denotes strains showing an intermediate level of $\mathrm{Alb}^{\mathrm{r}}$; see Fig. 1 (b).

† Strains denoted B. Bachmann were kindly provided by Dr Barbara Bachmann, E. coli Genetic Stock Center, Yale University, CT, USA.

Unless stated otherwise, the mixture of albicidins obtained after HW-40 (S) chromatography was used in experiments reported here. To ensure that antibiotics produced by Australian isolates of $X$. albilineans were typical of albicidins described from Hawaiian isolates (Birch \& Patil $1985 a, b$ ), we confirmed that albicidin-sensitive strains of $E$. coli were inhibited around colonies of $X$. albilineans, whereas mutants selected for resistance to pure albicidin were not inhibited, and vice versa.

Selection of albicidin-resistant mutants. Albicidin-resistant (Alb $\left.{ }^{r}\right)$ mutants of $E$. coli strains were selected using a gradient-plate technique (Gerhardt, 1981), or by plating untreated cell suspensions onto plates of $\mathrm{Z}$ agar ( $1 \mathrm{~g}$ glucose, $10 \mathrm{~g}$ tryptone, $5 \mathrm{~g}$ yeast extract, $10 \mathrm{~g} \mathrm{NaCl}, 0.4 \mathrm{~g}$ $\mathrm{CaCl}_{2} \cdot 2 \mathrm{H}_{2} \mathrm{O}, 15 \mathrm{~g}$ agar per litre of water) containing $100 \mathrm{ng}$ albicidin $\mathrm{ml}^{-1}$.

Scoring albicidin and phage resistance. In mapping and cloning experiments, colonies were tested for resistance or sensitivity to albicidin by patching them, using sterile toothpicks, onto $Z$ agar plates containing $100 \mathrm{ng}$ albicidin $\mathrm{ml}^{-1}$. Resistance to phage $\mathrm{T} 6$ was tested by patching colonies onto $\mathrm{Z}$ agar plates spread with $0.1 \mathrm{ml}$ of a $\mathrm{T} 6$ lysate (about $10^{10}$ p.f.u. $\mathrm{ml}^{-1}$ ); the results were confirmed by cross-streaking bacteria against phage on $Z$ agar plates (Gerhardt, 1981). Doseresponse relationships to albicidin were determined as previously described (Birch \& Patil, 1985a), except that basal layers were of $\mathrm{Z}$ agar rather than minimal medium.

Effect of albicidin on phage replication. Multiplication of phages T4 and T7 was tested in E. coli strains RRI, RRI Albr, Q358 and Q358 $\mathrm{Alb}^{\mathrm{r}}$, both in the presence and absence of albicidin. Bacterial cells from an overnight culture in $\mathrm{Z}$ broth were resuspended at $10^{6}$ cells $\mathrm{ml}^{-1}$ in MC buffer (Miller, 1972) with $10^{4}$ p.f.u. $\mathrm{ml}^{-1}$ of phage and allowed to adsorb for $5 \mathrm{~min}$ at $24^{\circ} \mathrm{C}$. Suspensions were then diluted 10 -fold into $\mathrm{Z}$ broth or $\mathrm{Z}$ broth containing $100 \mathrm{ng}$ albicidin $\mathrm{ml}^{-1}$ and incubated at $37^{\circ} \mathrm{C}$ with gentle shaking. Samples were withdrawn at intervals and plated in soft agar seeded with sensitive bacterial cells to detect any increase in phage titre, which would indicate replication and subsequent release after host-cell lysis. Inhibition of phage replication was indicated by absence of a burst of phage release within $3 \mathrm{~h}$ incubation in these one-step growth experiments. 


\begin{abstract}
Mapping and cloning of alb locus. The approximate location of the gene controlling albicidin sensitivity $(a l b)$ was determined by estimating the frequency of cotransfer of albicidin sensitivity with selected amino acid markers mobilized from E. coli Q358(pULB113) Rif' to the polyauxotrophic Alb ${ }^{r}$ strain CSH57A, as described by Van Gijsegem \& Toussaint (1982). Fine mapping was undertaken using the generalized transducing phage $\mathrm{P} 1 \mathrm{~cm} t \mathrm{t}$, essentially as described by Miller (1972).

Cloning into plasmid pBR322 and into cosmid pHC79 used published protocols (Pühler \& Timmis, 1984) and biochemicals from Boehringer-Mannheim.
\end{abstract}

Thymidine uptake. The rate of transport of $\left[{ }^{3} \mathrm{H}\right]$ thymidine into cells (Hankte, 1976) was compared for several E. coli strains and related Albr mutants.

The effect of albicidin on thymidine uptake was determined using Alb $^{\text {s }}$ E. coli strains $294 \mathrm{RecA}^{-}\left(\mathrm{Thy}^{+}\right.$) and KMBL1 789 (Thy ${ }^{-}$), by the same procedure in the presence and absence of albicidin at $100 \mathrm{ng} \mathrm{ml}^{-1}$ and $1 \mu \mathrm{g} \mathrm{ml}^{-1}$. An additional control treatment in these experiments included $1 \mathrm{~mm}$-adenosine, which is known to reduce thymidine uptake by competing for transport across the cytoplasmic membrane (KriegerBrauer \& Braun, 1980)

Albicidin uptake. E. coli strains were grown in Luria broth (Miller, 1972) with shaking at $37^{\circ} \mathrm{C}$ for approximately $4 \mathrm{~h}$ to an $\mathrm{OD}_{520}$ of 2.0 . Cells were harvested by centrifugation at $8000 \mathrm{~g}$ for $5 \mathrm{~min}$, washed in minimal medium $\left(6 \mathrm{~g} \mathrm{Na} \mathrm{NaO}_{4}, 3 \mathrm{~g} \mathrm{KH}_{2} \mathrm{PO}_{4}, 1 \mathrm{~g} \mathrm{NH} \mathrm{NH}_{4} \mathrm{Cl}\right.$, $2.5 \mathrm{~g} \mathrm{MgSO}_{4} .7 \mathrm{H}_{2} \mathrm{O}, 2 \mathrm{~g}$ glucose per litre of water), then resuspended in 0.01 times the original culture volume of minimal medium containing $100 \mathrm{ng}$ albicidin $\mathrm{ml}^{-1}$. At intervals after addition of albicidin, $0.2 \mathrm{ml}$ samples were removed and immediately centrifuged at $15000 \mathrm{~g}$ for 1 min. Supernatants were removed from the cell pellets, and the cells were washed once by resuspending in $0.2 \mathrm{ml}$ minimal medium and centrifuging at $15000 \mathrm{~g}$ for $1 \mathrm{~min}$. Albicidin activity remaining in the supernatant and in the wash was determined for each sample as described previously (Birch \& Patil, 1985a) except that E. coli UQM70 was used as the assay strain. Centrifugation rather than filtration must be used to separate cells from the surrounding medium because at these low albicidin concentrations substantial albicidin activity is lost by adsorption to glassfibre filters. A wash-step proved necessary to recover albicidins weakly adsorbed to the bacterial cell-surface. With $\mathrm{Alb}^{\mathrm{r}} E$. coli cells this wash recovers substantial albicidin activity which may otherwise wrongly be assumed to have been taken up by cells.

$D N A$ replication in permeabilized cells. The concentration of albicidin required to block replicative DNA synthesis was determined using intact cells of the PolA ${ }^{-}$EndA $^{-} E$. coli strain KMBL1789, as described previously (Birch \& Patil, 1985a), and was compared with the concentration required to inhibit DNA synthesis in toluenepermeabilized cells of the same strain prepared and assayed as described by Moses \& Richardson (1970).

\section{Results and Discussion}

\section{Albicidin-resistant mutants}

Two classes of spontaneous albicidin-resistant mutants were obtained from gradient plates: (a) apparently unstable or inducible mutants in which a high proportion of the population became phenotypically albicidinsensitive after a single subculture on non-selective medium; (b) stable mutants which remained resistant after many transfers through non-selective medium.
Only the stable mutant class was obtained from $\mathrm{Z}$ agar plates containing $100 \mathrm{ng}$ albicidin $\mathrm{ml}^{-1}$. These mutants showed an approximate 100-fold increase in albicidin resistance relative to their parent strains (Fig. 1). All subsequent experiments reported here were confined to stable mutants.

Albicidin-resistant $E$. coli strains carrying lysogenic phage $\lambda$ showed many turbid plaques when plated on media containing albicidin, suggesting phage induction by albicidin treatment. All agents which are known to induce the lytic cycle of phage $\lambda$ affect DNA replication (Roberts \& Devoret, 1983). Results discussed below indicate that albicidin-resistant $E$. coli strains fail to accumulate a lethal intracellular antibiotic concentration. However, sufficient albicidin apparently penetrates such cells to induce prophage $\lambda$.

\section{Approximate location and attempted cloning of the alb locus}

After patch-mating $E$. coli Q358(pULB113) Rif ${ }^{f}$ with $E$. coli CSH57A, transconjugants prototrophic for one of seven auxotrophic mutations of CSH57A were selected. One-hundred transconjugants of each type were patched to test for cotransfer of albicidin sensitivity. Cotransfer frequencies were $17 \%$ with $l e u, 91 \%$ with proC, $77 \%$ with purE and $0 \%$ with ile, trp, his and met. These data indicate that alb is located at 9 to $10 \mathrm{~min}$ on the $E$. coli chromosome.

To confirm this approximate location, E. coli W3747 (an $\mathrm{Alb}^{\mathrm{r}}$ strain carrying episome F13 and a corresponding chromosomal deletion from $6 \mathrm{~min}$ to $12 \mathrm{~min}$ ) was patch-mated with $E$. coli strains KL251 (an $\mathrm{Alb}^{\text {s }} \mathrm{ProC}^{-}$ RecA $^{-}$strain) and RRI (an $\mathrm{Alb}^{\text {s ProA }} \mathrm{A}^{-} \mathrm{RecA}^{+}$strain), selecting for transconjugants not requiring proline. All $\mathrm{Pro}^{+}$transconjugants of KL251 remained $\mathrm{Alb}^{s}$ whereas 38 of $40 \mathrm{Pro}^{+}$transconjugants of RRI were $\mathrm{Alb}^{\mathrm{r}}$. This suggested that the $\mathrm{Alb}^{\mathrm{r}}$ gene on $\mathrm{F} 13$ is recessive and confers albicidin resistance only in the $\operatorname{RecA}^{+}$strain following recombination and segregation.

Genomic libraries of $E$. coli strains Q358 and Q358 $\mathrm{Alb}^{\mathrm{r}}$ were prepared by cloning fragments from partial HindIII and Sau3AI endonuclease digests of chromosomal DNA into plasmid pBR322 and cosmid $\mathrm{pHC79}$, followed by transformation or transfection into suitable recipients. Although the $\mathrm{Alb}^{\mathrm{s}}$ gene was expected to be dominant, no $\mathrm{Alb}^{\mathrm{s}}$ clones were detected from several libraries screened. It was also expected that cloning into recombination-proficient recipients would allow transformants which received the recessive $\mathrm{Alb}^{\mathrm{r}}$ locus to be detected after recombination and segregation in some of the progeny, as described above for F13. Several $\mathrm{Alb}^{r}$ transformants were obtained in this manner, but when the plasmids in these transformants 


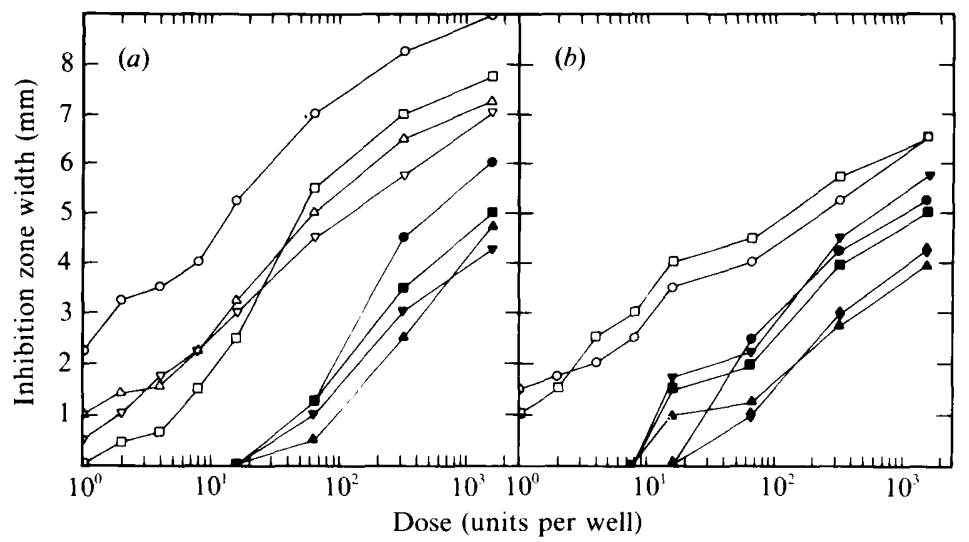

Fig. 1. Dose-response relationships for inhibition of growth of E. coli strains by albicidin. (a) Parent strains 294 (O), KL251 ( $\square$ ), Q358

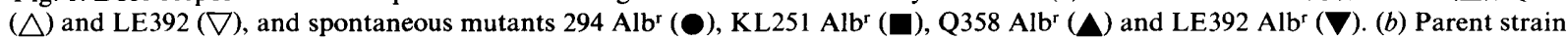

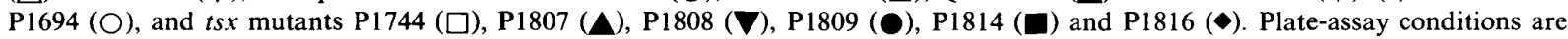
described in Methods. The results shown are from a typical experiment.

Table 2. Linkage relationship among proC, lac, alb and tsx

\begin{tabular}{|c|c|c|c|c|c|c|}
\hline \multicolumn{2}{|c|}{ Transduction } & \multirow{2}{*}{$\begin{array}{l}\text { Selected } \\
\text { marker }\end{array}$} & \multirow{2}{*}{$\begin{array}{l}\text { No. } \\
\text { tested }\end{array}$} & \multicolumn{3}{|c|}{$\begin{array}{l}\text { Frequency of unselected } \\
\text { donor marker }(\%)\end{array}$} \\
\hline Pl donor & Recipient & & & lac & $a l b$ & $t s x$ \\
\hline EMG2 & $\chi 478$ & proC $^{+}$ & 697 & 18 & 59 & 52 \\
\hline$\chi^{148}$ & $\chi^{342}$ & proC $^{+}$ & 600 & 12 & 59 & 59 \\
\hline Q358 Alb $^{r}$ & $\chi^{342}$ & proC $^{+}$ & 491 & - & 45 & 44 \\
\hline
\end{tabular}

were subsequently re-isolated and transformed into $E$. coli $\mathrm{Q} 358$, the $\mathrm{Alb}^{\mathrm{r}}$ gene was not transmitted with the plasmids. One possible explanation was instability of the high-copy-number plasmids carrying alb or adjacent genes.

It is known that albicidin selectively inhibits DNA synthesis without evidence of damage or binding to DNA, suggesting specific interaction with DNA polymerase or other DNA replication proteins (Birch \& Patil, $1985 a$ ). Of the known $E$. coli genes for DNA replication proteins, only dnaZ and dnaX (coding for subunits of DNA polymerase III) map within 2 min of alb.

Phages T4 and T7 code for their own replicative polymerases, and do not require host DNA polymerase III (Nossal, 1983). We therefore tested sensitivity of these phages to albicidin. Replication of phages $\mathrm{T} 4$ and

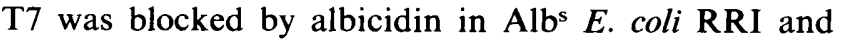
Q358, but not in $\mathrm{Alb}^{\mathrm{r}}$ mutants of these strains. Accordingly, the Albr mutations could affect albicidin uptake, albicidin inactivation or an $E$. coli gene involved in chromosome and in T4 and T7 replication. No such gene is known to map near the alb locus.
Precise mapping of the alb locus at tsx

Results of P1 transduction experiments to map the alb locus more accurately are shown in Table 2. All Albr transductants in these experiments were observed to be $\mathrm{T} 6^{\mathrm{r}}$. In contrast, a variable proportion of $\mathrm{T} 6^{\mathrm{r}}$ transductants remained Albs. However, a difficulty encountered in this work was the relatively high frequency at which spontaneous $\mathrm{T} 6^{\mathrm{r}}$ mutants arose; this may have contributed significantly to the apparent $\mathrm{T}^{\mathrm{r}} \mathrm{Alb}^{\mathrm{s}}$ transductants. Because of the very close linkage between $a l b$ and $t s x$ in transduction experiments, we selected more than 430 spontaneous $\mathrm{Alb}^{\mathrm{T}}$ mutants of strains $294 \mathrm{RecA}^{-}, \mathrm{Q} 358$, HB101, LE392 and RRI and tested their sensitivity to phage T6. All Albr mutants were found to have simultaneously become $\mathrm{T} 6^{\mathrm{r}}$, showing only a few plaques on cross-streaked plates, while the parent strains were completely lysed by $\mathrm{T} 6$.

However, in a reciprocal experiment not all $\mathrm{T}^{\mathrm{r}} \mathrm{E}$ E. coli strains were $\mathrm{Alb}^{\mathrm{r}}$. We selected non-mucoid $\mathrm{T} 6^{\mathrm{r}}$ (i.e. $t s x$ ) mutants of Q358, HB101 and $\chi 342$, and found that a 
variable proportion remained $\mathrm{Alb}^{\mathrm{s}}$. The proportion was dependent on the albicidin concentration in the testplates; many of the spontaneous tsx mutants selected appeared to gain resistance to low albicidin concentrations.

To examine this phenomenon further, we determined the dose-response relationships to albicidin for a series of $E$. coli tsx mutants known to have alterations in the structure or amount of the outer-membrane receptor protein encoded by the $t s x$ allele, as indicated by their ability to plate extended host-range mutants of phage T6 (Manning \& Reeves, 1978). Strain P1744 has a $t s x$ protein very similar to the parent strain P1694 (Manning \& Reeves, 1978) and showed similar albicidin sensitivity (Fig. $1 b$ ), whereas the other mutants with more substantially altered $t s x$ proteins showed decreased sensitivity to albicidin.

\section{Relationship between albicidin resistance and nucleoside uptake}

The $t s x$ gene product is an outer-membrane protein first recognized as the receptor for phage $\mathrm{T} 6$ and colicin $\mathrm{K}$, and now known to function in the transport of all nucleosides and deoxynucleosides, except cytidine and deoxycytidine, through the $E$. coli outer membrane (Krieger-Brauer \& Braun, 1980). The tsx protein is most effective in transport of nucleosides present at submicromolar concentrations in the surrounding medium, and supplies nucleosides for transport across the cytoplasmic membrane by two uptake systems termed nupC and nupG. These processes result in a $300-$ to 600 -fold intracellular concentration of nucleosides within $1 \mathrm{~min}$ of addition to the surrounding medium (Munch-Petersen $e t$ al., 1979).

Albicidin has a molecular mass of $842 \mathrm{Da}$, three to four times that of common nucleosides (Birch \& Patil, 1985b). However, albicidin supplied at approximately $0 \cdot 1 \mu \mathrm{M}$ acts within 1 min to specifically block DNA replication. This is a very low concentration for effective antibiotic activity. One hypothesis we proposed was that albicidin was actively accumulated as a nucleoside analogue via the $t s x$ protein outer-membrane channel, leading to inhibition of DNA replication at a higher intracellular concentration. Albicidin resistance in $E$. coli would, therefore, result from mutations at $t s x$ which reduced albicidin uptake. This would account for the recessive $\mathrm{Alb}^{\mathrm{r}}$ gene located at $t s x$, and the difficulty encountered in cloning the alb $(=t s x)$ gene. Other genes for outermembrane proteins are harmful in multiple copies (Stoker $e t$ al., 1982), and cloning of the intact $t s x$ gene has not been reported. Also consistent with this hypothesis was the observation that spontaneous $\mathrm{Alb}^{\mathrm{r}}$ mutants of

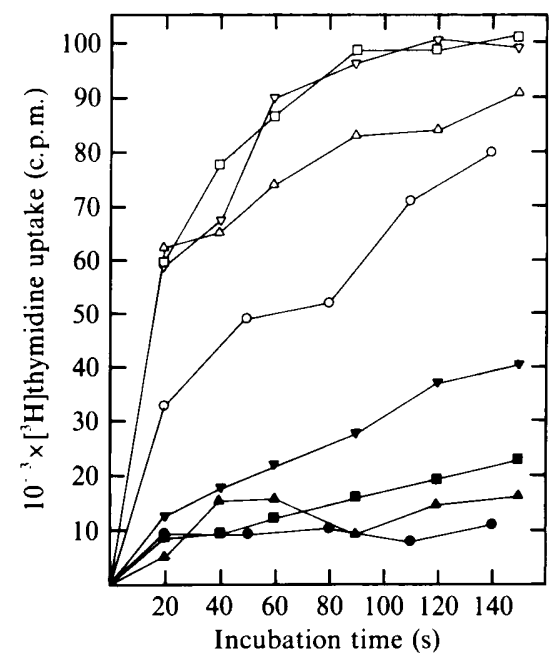

Fig. 2. Uptake of $\left[{ }^{3} \mathrm{H}\right]$ thymidine into $E$. coli parent strains $294(O)$, RRI ( $\square)$, Q358 $(\triangle)$, LE392 $(\nabla)$, and into spontaneous mutants 294

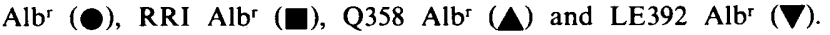
Exponential phase cultures in minimal medium at $\mathrm{OD}_{520}=0.26$ were supplied with $0 \cdot 1 \mu \mathrm{M}-\left[{ }^{3} \mathrm{H}\right]$ thymidine $\left[77 \mathrm{Ci} \mathrm{mmol}^{-1}\left(2.85 \mathrm{TBq} \mathrm{ml}^{-1}\right)\right]$ at time-zero. Thymidine uptake was measured by determining radioactivity in washed cells as described in Methods. The results shown are from a typical experiment.

several strains tested all showed reduced nucleoside uptake (Fig. 2).

Different chemical groupings on the $t s x$ protein are involved in receptor activities for T6 and colicin $\mathrm{K}$ (Hankte, 1976), and some changes in the conformation of the receptor can be matched by specific phage hostrange mutants (Manning \& Reeves, 1978; Riede et al., 1985). It seems probable, therefore, that some $t s x$ mutations may alter phage receptor activity without affecting albicidin-uptake activity, which would explain the existence of $\mathrm{T}^{\mathrm{r}} \mathrm{Alb}$ mutants. The absence of the reciprocal $\mathrm{Alb}^{\mathrm{r}} \mathrm{T}^{\mathrm{s}}$ mutants might then indicate that albicidin transport places less constraint on conformation of the $t s x$ protein channel than T6 receptor activity.

\section{Relationship between albicidin resistance and albicidin uptake}

Radioactive albicidin is not available for direct measurement of uptake by cells. Although albicidins can be extracted from washed albicidin-treated cells by $95 \%$ acetone, the dose-response relationship of the extracted activity differs from the applied activity, indicating alteration to albicidins in treated cells and precluding quantitative determination of uptake by this approach (data not shown). We therefore estimated albicidin uptake by following the removal of albicidin from the medium surrounding $\mathrm{Alb}^{\mathrm{s}}$ and $\mathrm{Alb}^{\mathrm{r}}$ E. coli cells, as described in Methods. 


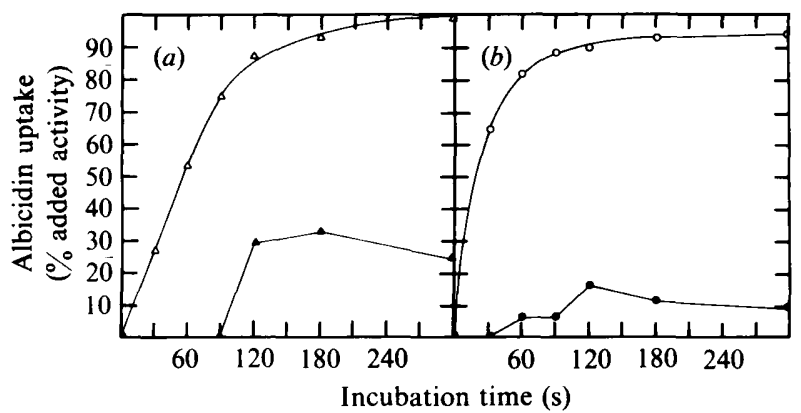

Fig. 3. Uptake of albicidin by $E$. coli strains. (a) Parent strain Q358 $(\triangle)$ and spontaneous mutant Q358 $\mathrm{Alb}^{\mathrm{r}}(\mathbf{A})$. (b) Parent strain BRE2050 (O) and isogenic $\Phi($ ts $x$-lacZ) $I$ (Hyb) fusion derivative strain GP4 (O). Albicidin uptake was estimated by following the removal of albicidin from the medium surrounding cells, as described in Methods. Data points are means of two replicates. The results shown are from a typical experiment.

The albicidin-sensitive $E$. coli strain Q358 rapidly removed albicidin from the surrounding medium, whereas the spontaneous $\mathrm{Alb}^{\mathrm{r}}$ mutant of this strain did not (Fig. $3 a$ ). The difference in rates of albicidin removal closely resembled the difference in rates of nucleoside uptake by these strains (Fig. 2).

To provide a more rigorous test of our hypothesis that albicidin resistance in $E$. coli results from mutations at $t s x$ which reduce albicidin uptake, we investigated an isogenic pair of $E$. coli strains differing only in one thoroughly characterized mutation which eliminates production of the Tsx protein. E. coli strain BRE2050 is $\mathrm{Tsx}^{+}$; strain GP4 is identical to BRE2050 except for an insertion mutation that generates a $t s x-l a c Z$ protein fusion close to the amino-terminus of Tsx, so that strain GP4 does not produce any Tsx protein (Bremer et al., 1988). Strain BRE2050 is $\mathrm{Alb}^{\mathrm{s}}$ and rapidly removed albicidin from the surrounding medium; strain GP4 was $\mathrm{Alb}^{\mathrm{r}}$ and showed greatly reduced albicidin uptake (Fig. $3 b$ ).

\section{Effect of albicidin on DNA replication in permeabilized cells}

The hypothesis of rapid intracellular accumulation of albicidin also leads to the prediction that DNA replication in a permeabilized cell system will appear less-sensitive to albicidin than in intact cells of an albicidin-sensitive strain. This was indeed the case, as shown in Fig. 4. A 100-fold increase in albicidin concentration over that effective in intact cells was necessary to achieve rapid inhibition of DNA replication in permeabilized cells. Lower albicidin concentrations caused a slower, partial inhibition of DNA replication in permeabilized cells, presumably due to delay in contact

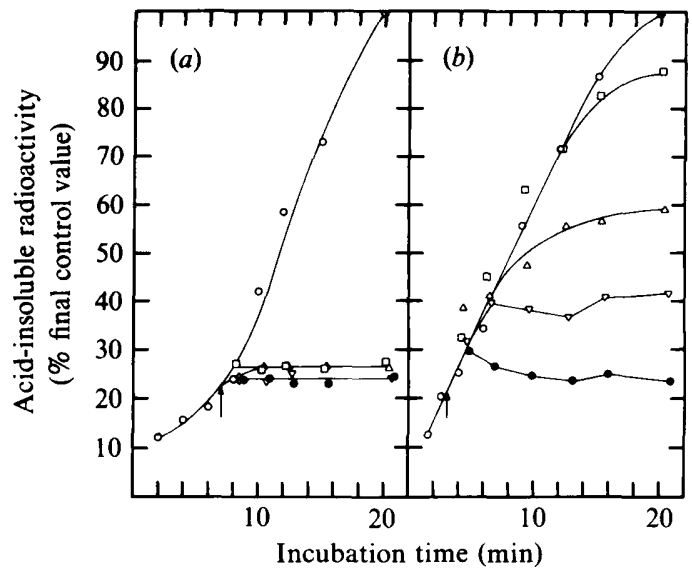

Fig. 4. Effect of albicidin on DNA synthesis in intact $(a)$ and toluenepermeabilized $(b)$ cells of $E$. coli KMBL1789. O, Control; $\square, 100 \mathrm{ng}$ albicidin $\mathrm{ml}^{-1} ; \triangle, 1 \mu \mathrm{g}$ albicidin $\mathrm{ml}^{-1} ; \nabla, 10 \mu \mathrm{g}$ albicidin $\mathrm{ml}^{-1} ; \boldsymbol{\bullet}$, $3 \mathrm{~mm}-\mathrm{N}$-ethylmaleimide. Arrows indicate time of addition of antibiotic to cell suspensions previously supplied with the labelled precursors $\left[{ }^{3} \mathrm{H}\right]$ thymidine $(a)$ and $\left[{ }^{3} \mathrm{H}\right]$ thymidine 5-triphosphate $(b)$. Radioactivity incorporated into the acid-insoluble fraction was determined at intervals, as described in Methods. Final c.p.m. $\mathrm{ml}^{-1}$ for control samples, plotted as 100 radioactivity units, were (a) $11.9 \times 10^{3}(a)$ and $15 \cdot 2 \times 10^{3}(b)$. The results shown are from a typical experiment.

between albicidin and its molecular target at lower concentrations. These results with the PolA-EndAstrain KMBL1789 provide direct evidence that replicative DNA synthesis is blocked by albicidin; use of the permeabilized cell system with all necessary deoxynucleoside triphosphates provided confirms that the target of albicidin is indeed the DNA replication machinery rather than precursor biosynthesis or uptake (Birch \& Patil, 1985a).

\section{Absence of competition between albicidin uptake and nucleoside uptake}

Albicidin did not interfere with nucleoside uptake by $E$. coli (Table 3) and added nucleosides do not protect $E$. coli from albicidin (Birch \& Patil, 1985a). This finding can be contrasted with that for the maleimide antibiotic showdomycin, which is transported across the cytoplasmic membrane by the nupC system but does not use the $t s x$ channel. A wide variety of nucleosides protect $E$. coli from showdomycin by competitive inhibition of showdomycin uptake, and showdomycin-resistant mutants have an altered cell-membrane nucleoside transport system (Komatsu, 1981). The difference arises because nucleosides do not compete with each other for transport through the $t s x$ channel, but do compete for transport across the cytoplasmic membrane (Krieger-Brauer \& 
Table 3. Effect of albicidin on uptake of thymidine by E. coli

Thymidine uptake was measured as c.p.m. $\mathrm{ml}^{-1}$ in washed cells 2 min after addition of $\left[{ }^{3} \mathrm{H}\right]$ thymidine at $0 \cdot 1 \mu \mathrm{M}$. Results are means of two replicates, expressed as a percentage of the water control. Control values were: $294 \mathrm{RecA}^{-}, 9.9 \times 10^{5}$ c.p.m. $\mathrm{ml}^{-1}$; KMBL1789, 8.0 × $10^{5}$ c.p.m. $\mathrm{ml}^{-1}$.

\begin{tabular}{lcccc}
\hline \hline \multirow{2}{*}{$\begin{array}{l}\text { E. coli } \\
\text { strain }\end{array}$} & $\begin{array}{c}\mathrm{H}_{2} \mathrm{O} \\
\text { control }\end{array}$ & \multicolumn{3}{c}{ Thymidine uptake in the presence of: } \\
\cline { 3 - 5 } & $100 \mathrm{ng} \mathrm{Alb} \mathrm{m}^{-1}$ & $1 \mu \mathrm{g} \mathrm{Alb} \mathrm{ml}^{-1}$ & 1 mM-Adenosine \\
\hline 294 RecA- & 100 & 127 & 138 & 15 \\
KMBL1789 $^{100}$ & 100 & 131 & 143 & 10 \\
\hline \hline
\end{tabular}

Braun, 1980). We have not obtained stable Albr mutants of $E$. coli which are unaltered at $t s x$, so the route of albicidin transport across the cytoplasmic membrane remains unknown.

\section{Conclusion}

We conclude that albicidin is effective at very low concentrations against $E$. coli because it is rapidly concentrated within cells by illicit transport mediated by the $t s x$-encoded outer-membrane channel normally involved in nucleoside uptake. Albicidin resistance in $E$. coli maps at or adjacent to $t s x$, is accompanied by resistance to phage T6 and results from loss of the mechanism of albicidin transport through the outer membrane.

Other bacteria sensitive to low concentrations of albicidin presumably also accumulate the antibiotic intracellularly as a nucleoside analogue, but mechanisms of resistance may differ to that in E. coli. We have, for example, recently investigated albicidin resistance in Klebsiella oxytoca and discovered a gene for an albicidinbinding protein which confers high-level albicidin resistance when expressed in E. coli (Walker et al., 1988).

It may be possible to detect other mechanisms of spontaneous albicidin resistance in $E$. coli by plating a Thy ${ }^{-}$strain on media containing albicidin and a low concentration of the required nucleoside. Any resulting $\mathrm{Alb}^{\mathrm{r}}$ mutants would be expected to have an altered nucleoside-uptake system capable of excluding albicidin while transporting thymidine, or to have a different mechanism such as an albicidin-resistant target. We are interested in such mechanisms as they may prove applicable to obtain albicidin-resistant plant cells by selection or genetic transformation.

We gratefully acknowledge support for the research from the Utah Foundation, the Queensland Sugar Experiment Stations Board and the Australian Research Council.

\section{References}

Birch, R. G. \& Patil, S. S. (1983). The relation of blocked chloroplast differentiation to sugarcane leaf scald disease. Phytopathology $\mathbf{7 2}$, 1368-1374.

BIRCH, R. G. \& PATIL, S. S. (1985a). Preliminary characterization of an antibiotic produced by Xanthomonas albilineans which inhibits DNA synthesis in Escherichia coli. Journal of General Microbiology 131, 1069-1075.

BIRCH, R. G. \& PATIL, S. S. (1985b). Antibiotic and process for the production thereof. United States Patent \#4,525,354.

BIRCH, R. G. \& PATIL, S. S. (1987a). Correlation between albicidin production and chlorosis induction by Xanthomonas albilineans, the sugarcane leaf scald pathogen. Physiological and Molecular Plant Pathology 30, 199-206.

BIRCH, R. G. \& PATIL, S. S. (1987b). Evidence that an albicidin-like phytotoxin induces chlorosis in sugarcane leaf scald disease by blocking plastid DNA replication. Physiological and Molecular Plant Pathology 30, 207-214.

Bremer, E., Gerlach, P. \& Middendorf, A. (1988). Double negative and positive control of $t s x$ expression in Escherichia coli. Journal of Bacteriology 170, 108-116.

GerhardT, P. (editor) (1981). Manual of Methods for General Bacteriology, pp. 234 and 262. Washington, DC: American Society for Microbiology.

HankTe, K. (1976). Phage T6-colicin $K$ receptor and nucleoside transport in Escherichia coli. FEBS Letters 70, 109-112.

KOMATSU, Y. (1971). Mechanism of action of showdomycin. V. Reduced ability of showdomycin-resistant mutants of Escherichia coli K-12 to take up showdomycin and nucleosides. Journal of Antibiotics 24, 876-883.

KRIEGER-BraUer, H. J. \& BraUN, V. (1980). Functions related to the receptor protein specified by the $t s x$ gene of Escherichia coli. Archives of Microbiology 124, 233-242.

Maniatis, T., Fritsch, E. F. \& Sambrook, J. (1982). Molecular Cloning: a Laboratory Manual, pp. 504-506. Cold Spring Harbor, NY: Cold Spring Harbor Laboratory.

Manning, P. A. \& Reeves, P. (1978). Outer membrane proteins of Escherichia coli $\mathrm{K} 12$ : isolation of a common receptor protein for bacteriophage T6 and colicin K. Molecular and General Genetics 158, 279-286.

MILLER, J. H. (1972). Experiments in Molecular Genetics, pp. 201-205. Cold Spring Harbor, NY: Cold Spring Harbor Laboratory.

MosEs, R. E. \& RichaRDSON, C. C. (1970). Replication and repair of DNA in cells of Escherichia coli treated with toluene. Proceedings of the National Academy of Sciences of the United States of America 67, 674-681.

Munch-Petersen, A., Mygind, B., Nicolaisen, A. \& Pihl, N. J. (1979). Nucleoside transport in cells and membrane vesicles from Escherichia coli K12. Journal of Biological Chemistry 254, 3730-3737.

Nossal, N. G. (1983). Prokaryotic DNA replication systems. Annual Review of Biochemistry 53, 581-615. 
Pühler, A. \& Timmis, K. N. (1984). Advanced Molecular Genetics, pp. $160-170$ and pp. 190-201. Berlin: Springer-Verlag.

Riede, I., Degen, M. \& Henning, U. (1985). The receptor specificity of bacteriophages can be determined by a tail fibre modifying protein. EMBO Journal 4, 2343-2346.

ROBERTS, J. W. \& DEVORET, R. (1983). Lysogenic induction. In Lambda II, pp. 123-144. Edited by R. W. Hendrix, J. W. Roberts, F. W. Stahl \& R. A. Weisberg. Cold Spring Harbor, NY: Cold Spring Harbor Laboratory.

Stoker, N. G., Fairweather, N. F. \& Spratt, B. G. (1982). Versatile low-copy-number plasmid vectors for cloning in Escherichia coli. Gene 18, 335-341.
Uhlin, B. E., Schweickart, V. \& Clark, A. J. (1983). New runaway replication-plasmid cloning vectors and suppression of runaway replication by novobiocin. Gene 22, 255-265.

VAN GiJSEGEM, F. \& Toussaint, A. (1982). Chromosome transfer and R-prime formation by an RP4::mini-Mu derivative in Escherichia coli, Salmonella typhimurium, Klebsiella pneumoniae and Proteus mirabilis. Plasmid 7, 30-44.

Walker, M. J., Birch, R. G. \& Pemberton, J. M. (1988). Cloning and characterisation of an albicidin resistance gene from Klebsiella oxytoca. Molecular Microbiology 2, 443-454. 